\title{
Active Learning Methods-An Analysis of Applications and Experiences in Brazilian Accounting Teaching
}

\author{
Adriana Maria Procópio de Araujo, Vilma Geni Slomski \\ ${ }^{1}$ University of São Paulo, College of Economics, Administration and Accounting, Ribeirão Preto, Brazil \\ ${ }^{2}$ Álvares Penteado School of Commerce Foundation-FECAP, São Paulo, Brazil \\ Email: amprocop@usp.br, vilma.geni@fecap.br
}

Received November $9^{\text {th }}$, 2013; revised December $9^{\text {th }}$, 2013; accepted December $16^{\text {th }}, 2013$

Copyright (C 2013 Adriana Maria Procópio de Araujo, Vilma Geni Slomski. This is an open access article distributed under the Creative Commons Attribution License, which permits unrestricted use, distribution, and reproduction in any medium, provided the original work is properly cited. In accordance of the Creative Commons Attribution License all Copyrights (C) 2013 are reserved for SCIRP and the owner of the intellectual property Adriana Maria Procópio de Araujo, Vilma Geni Slomski. All Copyright (c) 2013 are guarded by law and by SCIRP as a guardian.

\begin{abstract}
In the cognitive form in which they develop their learning, human beings are submitted to a series of interfering factors for the process to happen. One of these factors is the way they absorb, learn and store knowledge. Constant questions on the teaching and learning process are discussed not only in pedagogy. The debate to improve education practices is present in any knowledge area and the issue is no different in the business area. This research aims to describe active learning methods as alternatives to improve the teaching and learning process in accounting. The study reveals the importance and use of active learning methods in accounting teaching and demonstrates what is being done in Brazil in this regard. The study presents some experiences to apply these methods in Brazilian literature, including problem based learning (PBL). A descriptive and exploratory research method is used. Based on the study, it is concluded that a knowledge process on active teaching methods applied to the business area is just beginning and that these can be used to improve the learning process of today's and future accounting professionals. Although few studies have been published in Brazil, the use of active learning methods has demonstrated efficiency and students' adherence, as it contributes to their learning process. In most cases, these methods are superior to traditional teaching methods.
\end{abstract}

Keywords: Active Learning Methods; Teaching Methods; Problem Based Learning

\section{Introduction}

Accounting professionals are responsible for creating structured analysis, suggestion and decision conditions for problem solving in the companies they are working in. Hence, accountants' profile should be compatible with market and corporate changes. This profile is a consensus in different countries and not exclusive to Brazilian professionals.

Social and professional demands for accountants demonstrate, besides the need for technical preparation, the development of specific skills. The education of future professionals requires skills development, critical-reflexive thinking and problemsolving abilities.

Neves (2006) argues that students today benefit from the quantity and speed of information, creating distinctive characteristics when compared to former professionals. One of these characteristics is the easy adaptation to moving images, as well as a peculiar form of language, mainly required by the use of internet resources, which entail a new profile for higher education candidates.

According to the author, as a result of this scenario, students

"Paper presentation in PBL2010 International Conference - Problem-Based Learning and Active Learning Methodologies, http://www.uspleste.usp.br/pbl2010/index_en.htm. no longer want to know how things work, but how they can make things work and interact with reality, representing a challenge for traditional lectures which, despite support from audiovisual resources, may not be attractive for this new student profile. Students may face difficulties to assimilate these lectures with the support of static images.

Andrade (2002) mentions that faculty members, students and teaching institutions should research, discuss and try out alternatives with a view to improving the efficiency and efficacy of the teaching-learning process, completing the gaps created by the continuity of traditional methods.

The transformations in this generation of students and the updating itself of Brazilian and global accounting legislation standards and rules broaden the gaps in teaching-learning even more. These should be completed in order to improve teaching quality and efficacy.

One way of working with the diversity in job market needs and students' anxieties is the use of distinguished pedagogical methods. This means moving from the teacher's active position to students' active position.

Constant inquiries about the teaching-learning process go beyond the pedagogy area itself. This debate gains distinctive characteristics in the corporate area, to the extent that the association between theory and practice is needed for the sake of 
efficient professional activity.

Hence, in all activity areas and, in this case particularly in Accountancy teaching, reflecting on innovative teaching and learning forms led to a necessary change in the role of education and school, allying education and professional qualification as a fundamental process for competitiveness, which started to be part of the global job scenario.

Undergraduate business courses in which accounting is taught and professional training courses demand faculty with professional experience and a compatible theoretical background to add relevant information to students. A strong operating and physical structure is not enough to teach course subjects. Contents and knowledge transmitters need to be constructed that are compatible with the target public's expectations. The target public of accountancy courses necessarily comprises future and already graduated professionals.

A literature search reveals that the teaching method serves as a lever for the learning process. Active learning methods are methods in which techniques are used in the learning process to achieve the participant (student)'s active insertion in the process. Seeking teaching alternatives with the use of active teaching methods is a constant in this high-tech and high-speed information context.

The pedagogical method can be understood as the teaching methods, and a given knowledge area develops in the attempt to reach goals.

According to Nérici (1977: p. 277), teaching method is "the set of logically coordinated moments and techniques, with a view to driving the student's learning towards certain objectives”.

Basically, teaching method is the route towards an objective. According to Libâneo (1994), methods are the adequate means to accomplish objectives. Each knowledge area develops its own methods, such as mathematical methods, sociological methods, pedagogical methods, etc.

Therefore, an inquiry is due to reflect on the teaching methods that are being used to prepare professionals. What is research in this regard looking at around the world? What correlated research is being done in Brazil?

In view of those inquiries, this research looks at the following problem: what do studies point towards active learning methods in Brazilian accountancy teaching?

Thus, the purpose of this research is to describe theory on active learning methods in a general sense, as well as the importance and use of active learning methods in accounting teaching and to demonstrate what is being done with regard to this issue in Brazil. This is a descriptive and exploratory study. Therefore, no specific topic on methodological procedures will be presented. Instead, procedures will be described inside each topic.

This paper is structured as follows: initially, relevant questions are discussed in the debate on methodological approaches, followed by a presentation of active learning methods and what is being discussed about the theme in the main international journals. Then, a summary of the research is included, as well as the characteristics of Brazilian publications. Finally, the study conclusions indicate the superiority of active learning methods in accounting teaching when compared with traditional teaching methods.

\section{Theoretical Framework}

The theoretical framework of this study is based on key con- cepts, which will be clarified because they guide the analytic perspectives in the results and discussion section. Thus, concepts, implications and foundations will be addressed for the use of active learning methods, as well as different studies found in the literature.

\section{Methodological Approaches}

Methodological approaches are seen as a means to study theory-based methodological processes. The way in which a given approach is put in practice is the teaching method.

The different pedagogical lines or trends in Brazilian teaching, called "methodological approaches", could offer "guidelines for teaching action, even when considering that each teacher elaborates them in an individual and untransferable way” (Mizukami, 1986).

Learning theories, in psychology and education, are the various models that explain individuals' learning process. Contributions by Ausubel, prioritizing significant learning with a cognitive structure, by Piaget, in the study of cognitive development, and Vygotsky, in the theory in which children's intellectual development occurs in function of social interactions and living conditions, were somehow fundamental for the evolution of the teaching and learning process in recent years. This paper does not intend to study these and other theories on the subject, nor on the accounting area. What is needed is to make good use of these theories and then, based on the learning process, study the methodological approaches appropriate to the needs of accounting education.

Learning process is considered as the way students acquire knowledge, develop competences and modify their behavior. Teaching methods are the routes to reach an end, that is, the routes needed for the learning process to be done correctly. How accounting is taught in Brazil remains a question without a scientific answer. Common sense contains different perceptions on how teaching takes place, but not scientific discussion. Likewise, there are no ongoing discussions about how graduates learn or should learn accounting. What is known is that, in many situations, students do not learn what is essential and goes through a lot of difficulty to graduate, resulting in professionals without many perspectives.

The entire accountancy framework in Brazil, as a knowledge area and specifically in the field of applied social sciences, is based on behavioral theory, following Skinner's approach (after 1930). The essence of this theory is the premise that human behavior is understood in function of operating behavior. Nevertheless, other research in psychology and education have advanced on this concept and this research does not aim to go deeper into questions on what theory best applies to accounting teaching. Instead, knowing them is one of this study's concerns.

In Brazil, we do not know which methodological lines or approaches predominate in accounting teaching. Therefore, the approaches by Mizukami (1986) were chosen, who is a renowned researcher in Brazilian higher education and summarizes the pedagogical theories and doctrines in a study focused on knowledge about teaching approaches. The proposal is to find out how teaching takes place, considering the following approaches: 1) traditional approach; 2) behavioral approach; 3) humanistic approach; 4) cognitive approach; and 5) sociocultural approach.

In the traditional approach, the transmission of ideas is logically selected and organized. Mizukami (1986) quotes that 
intelligence is a faculty capable of storing information, ranging from the most simple to the most complex.

This approach is recognized in Paulo Freire's "banking education" studies, in which the educator "deposits" knowledge, information, data etc. in the student.

In the behavioral approach, the teacher controls the learning process and is responsible for knowledge transmission, while the students take the learning role. Teachers teach and, at the same time, should stimulate students to learn.

The proposal of the humanistic approach is for human beings to develop without any influence, observing a person's interpersonal relations and personality growth in the construction and personal organization of each individual's reality. In this case, the teacher is seen as a facilitator of the teaching and learning process.

The cognitive approach concentrates on the students' information integration and processing capacity. The way students organize knowledge is emphasized, how they process information, directly relate to their way of thinking or cognitive styles. Piaget and Brumer are responsible for the main studies in this approach. At the start of the 1990's, Skinner (1990) recognized and questioned the learning process using cognitive bases, although he was a complete follower of behavioral theory.

In the sociocultural approach, knowledge development is related to the awareness process. Roles are inverted and the student becomes the educator in the teaching-learning process.

According to Freire (1987), there is no other route than that of humanizing pedagogical practice through a permanent dialogical relation. Hence, problematizing education is "a permanent effort through which men critically perceive how 'they are being' in the world with 'what' and 'in what' they find themselves” (Freire, 1987: p. 41).

According to Mizukami (1986, p. 4), different pedagogical lines or trends in Brazilian teaching, which the author calls "approaches", could provide "guidelines for teaching action, even when considering that each teacher elaborates them in an individual and untransferable way". Picture 1 summarizes these approaches and relates them with teaching methods.

Methodological approaches - traditional/behavioralist/cognitive/ sociocultural—teaching methods

Choosing one approach only, however, would not be ideal to reach the goal of preparing students as well as possible. Specialization in one of these would not be the case either. What is interesting is interaction between ways of working with the teaching and learning process, with a view to improving the accounting teaching process.

\section{Active Learning Methods}

Active learning methods are methods in which the teaching emphasis is centered on the student. The students' role changes from passive to active in the process, often assuming the main role in their own learning.

In traditional teaching methods, the use of teaching methods is basically teacher-based, and the student merely receives the content. The teacher is responsible for learning, while the student in most cases plays the role of a mere receiver and is a passive participant in the learning process.

The contributions of Ausubel, prioritizing cognitive learning, and Vygotsky to learning development (Leif and Rustin, 1968) structure later discussions like Piaget and, more recently, Freire.

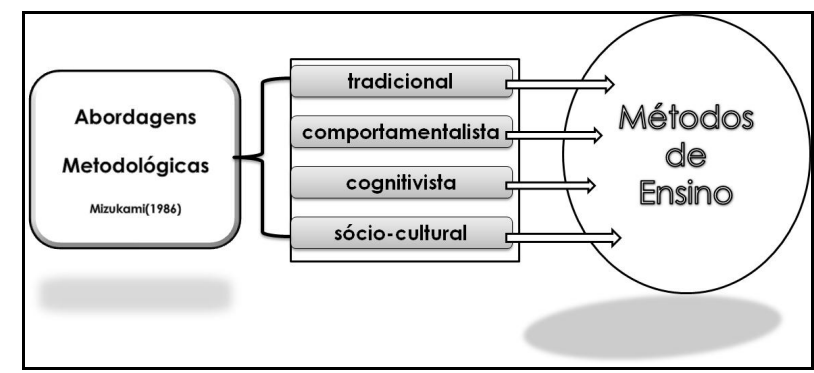

\section{Picture 1.}

Methodological approaches. Source: Mizukami, 1986, adapted by the authors.

The big challenge at the start of this century is the perspective of individual autonomy developing in close coalition with the collective. Education should be capable of unleashing a view of the whole - of interdependence and cross-disciplinarity -, besides permitting the construction of networks of social changes, with the consequent expansion of individual and collective awareness. Therefore, one of its merits is exactly the growing trend to seek innovative methods, which permit ethical, critical, reflexive and transformative practice, moving beyond the boundaries of purely technical training to effectively achieve man's formation as a historical being, inscribed in the dialectics of action-reflection-action (Mitre et al., 2008: p. 4).

The main benefits of using active learning methods are: contributing to the study of a topic from different perspectives; expanding students' awareness about tolerance to bias and complexity; stimulating other students' respect, opinions and experiences; developing cooperative learning habits; helping students in the development of synthesis and integration skills; affirming students as co-producers of knowledge; encouraging students to acknowledge and investigate their premises; among others.

There are different traditional teaching methods, which can be used in a wide range of forms. These include: lectures (most common form), use of blackboard notes, note boards, presentations on a given topic, slides to present certain contents. These methods are not necessarily decaying, nor do they fail to reach the goal of students' learning, but either the teacher should be self-assured and master the contents in order to transmit knowledge and make students learn, or these methods will be frustrating.

Graduates today are different from graduates five years ago and the learning process should obviously accompany man's evolution. Independently of the country where the student actually studies, differences are clear. But different in what aspects? In the cognitive form in which their learning is developed, human beings are submitted to a series of interfering factors for the process to occur. One of these factors is the way in which man absorbs, learns and stores knowledge. In a generation in which high technology is a reality and information evolves at an absurd speed, maintaining the same teaching form as in the last decade may, in different circumstances, no longer attend to the needs of the student public. Educators become obliged to seek alternative active methods. In the accounting area, in which the teaching situation should be as close as possible to the actual market situation, these methods only contribute to the learning process.

The most common active learning methods are: seminars, case studies, project-based learning and problem based learning 
(PBL), among others. Chart 1 shows some active learning methods and their main characteristics.

Some of the above methods are known and end up being used in daily teaching, even without their formal name. There is no formal or theoretical indication on when to use one or another method. The most adequate method should be used to reach the intended goal, aiming for the student's optimal learning.

It is a utopia to elect the most important method. All methods have advantages and applications. Disadvantages are also detected in the lack of knowledge about each method and in cases of unstructured and unplanned application. In those situations, the method will not facilitate the learning process for the student, but can easily turn into a learning problem.

\section{Research on Teaching Method Publications}

When observing accounting teaching in Brazil, the general perception is that the teaching method centers on the comprehensive use of traditional methods, where the teacher is extremely necessary in the teaching-learning process. Students are passive agents in the process, assuming the role of receiving the information and experiences their teachers transmit. No research indicating or demonstrating this perception were identified in Brazilian literature.

The survey of research published in international databases (journals) that constituted the heuristics on the theme was based on the following parameters: (1) indexed in the Scopus system; (2) indexed in the Institute for Scientific Information (ISI); impact ratio in Journal Citation Report (JCR) above 0.5; pub- lished in the last ten years or available for on-line access. Keywords were also used to facilitate the search and identify publiccations of interest. Table 1 shows a summary of the survey:

The research also included the Journal of Accounting Education, which was not included in the above table because this specific journal debates accounting education issues, so that all papers somehow fit into the topic discussed in this research. In the heuristics, more than 200 papers were identified whose abstracts contained the selected keywords.

After constructing the heuristics on accounting teaching, methodology and education, the search looked at references about the use of active learning methods in accounting. The topic is identified in some international journals. The study by Cottell Jr and Millis (1992) discusses the use of study groups to improve students' performance in the accounting learning process. These authors call the method learning cooperatives in accounting.

Hand, Sanderson and O’Neil (1996) investigated the use of active learning methods for the business area, specifically for accounting teaching, and concluded that these methods need to be used for a better assessment of the teaching-learning process.

In another research, by Kanet and Barut (2003), the active learning method is used for business teaching in an MBA (Master in Business Administration) course. The researchers adopted the PBL method in a specialization course and presented statements about the success of and adherence to the method. Applications of the PBL methods in accounting teaching can also be studied in Johnstone and Biggs (1998), Milne and McConnell (2001), Hansen (2006), among others.

\begin{tabular}{|c|c|c|}
\hline Method & Application & Some Advantages \\
\hline Discussion & $\begin{array}{l}\text { The teacher presents the theme and then makes room } \\
\text { for class discussion; small discussion groups can be } \\
\text { organized, with the teacher closing off the topic after } \\
\text { the groups' presentations. }\end{array}$ & $\begin{array}{l}\text { * favors reflection on what was learned, } \\
\text { * opportunities for students to present their ideas; } \\
\text { * students' awareness on the problems presented; } \\
\text { * favors students' learning how to think; } \\
\text { * stimulates students' involvement; } \\
\text { * favors teacher-student relations. }\end{array}$ \\
\hline Seminars & $\begin{array}{l}\text { Students present research themes and topics predefined } \\
\text { by the teacher. Can be individual or in group. }\end{array}$ & $\begin{array}{l}\text { * favors the dissemination of ideas; } \\
\text { * develops skills for communication in public; } \\
\text { * favors the construction of ideas; } \\
\text { * ability to synthesize topics; } \\
\text { * stimulates group learning. }\end{array}$ \\
\hline PBL & $\begin{array}{l}\text { Student groups are constituted with predefined roles, } \\
\text { called tutorial group: leader, secretary and other group } \\
\text { participants; the teacher presents the research problem } \\
\text { situation; the teacher plays the role of tutor and only } \\
\text { guides each group's tasks. }\end{array}$ & $\begin{array}{l}\text { * facilitates understanding of topics; } \\
\text { * favors learning in the interdisciplinary context; } \\
\text { * students are free to master their own learning; } \\
\text { * develops interpersonal and group work skills. }\end{array}$ \\
\hline Problematization & $\begin{array}{l}\text { Similar to PBL, but without a formal structure of role } \\
\text { division and script to follow; in this method, } \\
\text { problematization follows five pre-established steps: } \\
\text { reality, key points, theorization, solution hypotheses } \\
\text { and application to reality. }\end{array}$ & $\begin{array}{l}\text { * favors the presentation of different solutions for the same problem; } \\
\text { * develops creativity; } \\
\text { * creates self-assurance to solve problems; } \\
\text { * develops observation and application skills in the real world. }\end{array}$ \\
\hline $\begin{array}{l}\text { Project-Based } \\
\text { Learning }\end{array}$ & $\begin{array}{l}\text { In the project-based method, the teacher passes all } \\
\text { steps to construct a project to the students; the student } \\
\text { is completely active in the process. }\end{array}$ & $\begin{array}{l}\text { * develops planning and organization skills; } \\
\text { * creates students' habit to use scripts ant timetables; } \\
\text { * facilitates students' self-criticism in the assessment of goal compliance }\end{array}$ \\
\hline Case Studies & $\begin{array}{l}\text { The teacher develops or applies a situation in which the student } \\
\text { should develop activities and present one or more solutions; } \\
\text { the teacher leads the process and stimulates the student's } \\
\text { ability to learn how to learn; can be individual or in group. }\end{array}$ & $\begin{array}{l}\text { * favors critical analysis skills; } \\
\text { * stimulates students to apply knowledge in the real world; } \\
\text { * develops leadership and problem-solving skills. }\end{array}$ \\
\hline Simulation & $\begin{array}{l}\text { The teacher passes different forms of problem situations } \\
\text { to the students, who look for options to solve the problems. }\end{array}$ & $\begin{array}{l}\text { * develops thinking skills; } \\
\text { * stimulates creativity; } \\
\text { * ability to discover different solutions to the same problem. }\end{array}$ \\
\hline
\end{tabular}

Chart 1.

Active learning methods. Source: elaborated by the authors. 
Table 1.

Summary of research published in international journals in the last five years.

\begin{tabular}{llcc}
\hline \multicolumn{2}{c}{ RESEARCH in international journals } & Key words \\
\hline \multicolumn{1}{c}{ Journals } & education teaching & methods teaching or learning & teaching accounting or education \\
1 & Issues in Accounting Education (AAA) & 15 & 6 \\
2 & Accounting, Organization and Society & 9 & 17 \\
3 & Journal of Accounting and Economics & & 3 \\
4 & Journal of Accounting Research & & 37 \\
5 & European Accounting Review & 13 & \\
6 & Decision Sciences Journal of Innovative Education & & \\
\hline
\end{tabular}

Source: elaborated by the authors.

In this knowledge process found in international studies, some deserve to be highlighted, although they were not necessarily included in the present research base. Dennis Gordon, an accounting faculty from Akron University, Ohio, discussed accounting teaching methods in the computerization process in an article published in the Accounting Review in 1962.

In that same year, Wiley Mitchell, a professor at Kansas University, presented a paper at the American Accounting Association (AAA) convention in Michigan, where he discussed the importance and use of accounting teaching methods for law students.

Returning to the indexed research base, in 1999, Sarah Bonner, a professor at the University of Southern California, published a study in Issues in Accounting Education in which she discussed that teaching methods should be in accordance with the learning form and the proposed teaching objective, and that anything to the contrary would jeopardize success.

Another study, published in Issues in Accounting Education in 2000 by Michael Maher, a professor at Washington University, discusses how teachers can improve management control teaching by using adequate methods.

With regard to the use of the PBL method, in 2003, John Kanet, a professor at Dayton University and Mehmet Barut, a professor at Barton School of Business and Wichita State University, presented a paper in Decision Sciences Journal of Innovative Education, discussing the application of active learning methods through the use of PBL to teach production administration in MBA courses since 1998. They present an efficacy test model to analyze the acceptance of PBL in compareson with other traditional teaching methods.

In 2007, Julia Shaftel, an educational psychology professor and Timothy Shaftel, a business professor, both at Kansas University, published another interesting study in Issues in Accounting Education. The paper presents a discussion on how the methods used in the teaching system (before entering business school) interfere in business learning and how they can be adjusted, if necessary, with a view to improving learning in the area.

In summary, various papers call attention to the study of teaching methods in the business area and specifically in accounting in this research.

Using the same data collection technique, the survey also looked at Brazilian journals, using the ranking of the Coordination for the Improvement of Higher Education Personnel
(CAPES), affiliated with the Brazilian Ministry of Education. CAPES periodically disseminates a ranking of the best journals classified in each knowledge area. Table 2 shows the results of that survey:

With regard to Brazilian research, two health journals appear in the list. There are at least two justifications for this choice: 1) being included in the CAPES ranking for the business area with classifications A1 and A2 and, 2) publishing articles that discuss teaching methods for the health area which can also be used in business.

Another observation related to the Revista de Administração Contemporânea (RAC), classified as B1. Eighty-four articles were identified with the keywords education and teaching. All papers are related to administration teaching in different activeity areas, but none was identified in accounting. The same is the case for journal B1- Revista de Administração de Empresas (RAE).

As this paper mainly looks at Brazilian research, next, papers published on active learning methods in the last five years will be discussed.

\section{Active Learning Methods in Brazil}

Pedagogy research has appointed active learning methods as a 'modernization' of the integration process between teaching and student staff, thus following the evolution of teaching. Different factors are related to the theme: (1) high level and quantity of information to be absorbed; (2) student-directed learning process; (3) cultural aspects related to the target public of learning, among others.

In health sciences, including medicine, dentistry, pharmacy, psychology, biological sciences, collective health, among others, there is constant discussion on appropriate teaching methods to improve the teaching-learning process.

With regard to the use of active learning methods in business, in Brazil, some studies were identified, which will be critically identified in further detail.

Chart 2 shows all papers identified in recent publications about the theme, used in the above described database and in the databases of four Brazilian and international congress annals held in Brazil and one accounting journal: (1) Congress of the National Association of Graduate Programs in Accountancy (ANPCONT), (2) University of São Paulo (USP) Accounting and Controllership Congress, (3) Encounter of the National Administration Graduate Program and Research Association 
Table 2.

Summary of research published in Brazilian journals in the last five years.

\begin{tabular}{llcc}
\hline \multicolumn{1}{c}{ RESEARCH in Brazilian journals } & Key words \\
\hline \multicolumn{1}{c}{ Journals } & $\begin{array}{c}\text { Education and } \\
\text { teaching }\end{array}$ & $\begin{array}{c}\text { Teaching and } \\
\text { learning methods }\end{array}$ & $\begin{array}{c}\text { Accounting teaching } \\
\text { or education }\end{array}$ \\
\hline 1 & Cadernos de Saúde Pública (FIOCRUZ) - ranking A1 & 1 \\
2 & BAR Brazilian Administration Review - ranking A2 & 12 \\
3 & Ciência \& Saúde Coletiva - ranking A2 & 9 & 2 \\
4 & Gestão de Produção (UFSCar) - ranking A2 & 9 & 1 \\
5 & Revista de Contabilidade \& Finanças - ranking B1 & & \\
6 & RAC Eletrônica (online) - ranking B1 & 84 & 9 \\
7 & RAC Revista de Administração Contemporânea - ranking B1 & 5 & 4 \\
8 & RAE Eletrônica - ranking B1 & 34 & \\
9 & RAE Revista de Administração de Empresas - ranking B1 & & \\
\hline
\end{tabular}

Source: elaborated by the authors

\begin{tabular}{|c|c|c|c|}
\hline No & Authors & Title & Year and Place of Publication \\
\hline 01 & Araujo and Rodrigues & $\begin{array}{l}\text { O ensino da contabilidade: Aplicação do método PBL nas disciplinas } \\
\text { de contabilidade de uma Instituição de Ensino Superior Particular” }\end{array}$ & $\begin{array}{l}2006 \text { Congresso USP de } \\
\text { Controladoria e Contabilidade }\end{array}$ \\
\hline 02 & Soares and Araujo & $\begin{array}{l}\text { Aplicação do método de ensino Problem Based Learning (PBL) } \\
\text { no curso de Ciências Contábeis: um estudo empírico }\end{array}$ & 2008 ANPCONT \\
\hline 03 & Soares, Araujo and Leal & $\begin{array}{l}\text { Evidências Empíricas da Aplicação do Método Problem-based } \\
\text { Learning (PBL) na Disciplina de Contabilidade Intermediária } \\
\text { do Curso de Ciências Contábeis }\end{array}$ & 2008 EnANPAD \\
\hline 04 & Borges Leal and Casa Nova & $\begin{array}{l}\text { Métodos dramáticos aplicados a intervenções socioeducativas } \\
\text { de Autogestão e Contabilidade }\end{array}$ & 2009 REPeC \\
\hline 05 & Araujo et al. & $\begin{array}{l}\text { Aplicação do Método Problem-based Learning (PBL) no de curso } \\
\text { de especialização em controladoria e finanças }\end{array}$ & 2010 PBL International Congress \\
\hline 06 & Souza and Casa Nova & $\begin{array}{l}\text { Focus Group aplicado ao ensino da contabilidade para avaliar a } \\
\text { percepção dos discentes sobre a participação de um jogo de papéis (role play) }\end{array}$ & 2010 PBL International Congress \\
\hline
\end{tabular}

Chart 2.

Application of active learning methods in accounting teaching. Source: elaborated by the authors.

(EnANPAD), (4) Problem Based Learning 2010 International Congress held in São Paulo and (4) Revista de Educação $e$ Pesquisa em Contabilidade (REPeC).

In paper number one "Accounting teaching: Application of the PBL method in accounting subjects at a Private Higher Education Institution", presented at the $6^{\text {th }}$ University of São Paulo Accounting and Controllership Congress in 2006, the authors report on the application of the PBL teaching method at a private higher education institution (HEI) in São Paulo State and specifically in accounting teaching to administration students. The method was simultaneously applied in two subjects: general accounting and management accounting. The study identifies students' dissatisfaction with learning accounting in the business administration program. Based on this dissatisfaction, the teacher responsible for the subject decided to try out a different teaching method to stimulate students' learning process and chose the teaching method based on the concepts of problem based learning (PBL). The study is limited by the punctual application of the method to certain groups at one HEI in a specific learning situation. The study presents no theoreticcal background on active learning methods, despite a generic and timely discussion of the PBL teaching method.

The second paper analyzed was published in 2008, “Application of the Problem Based Learning teaching method in the Accountancy course: an empirical study”. The authors applied PBL in introductory accounting teaching to accountancy students from an HEI in São Paulo State, during one semester, as part of the normal course curriculum. The result of this research was published in the annals of the ANPCONT 2008 congress. Limitations refer to the quantity of observations, that is, like in article number one, the application is limited to one single student group and, hence, to the particularities and situations of one moment in the teaching-learning process. With regard to criticism, in the positive sense, the paper presents a theoretical base for the use of the PBL method, as well as a model to analyze the method's efficacy, already tested by other authors that use PBL. In the negative sense, the paper does not go deeper into the theoretical aspect of learning. The result underlines the superiority of the method in comparison with traditional methods.

With regard to the third article, also published in 2008, entitled "Empirical Evidence of the Application of the PBL Method 
in Intermediary Accounting as part of an Accountancy Course”, the PBL method was applied in intermediary accounting teaching to accountancy students at an HEI in Minas Gerais. The study maintains the same applications as the previous studies, except that the subject is intermediary accounting now. As a result, greater adherence to the method is also detected in comparison with traditional teaching methods.

In 2009, an article published in REPeC ("Drama methods applied to socio-educative interventions in Self-management and Accounting") demonstrates the contributions of using drama techniques in socio-educative Self-management interventions (democratic management) and accounting in the context of non-formal education; two drama methods were used that are common in educative practices: Role-Playing (RP) and the Theatre of the Oppressed (TO). The authors use active learning methods as an alternative to improve the teachinglearning process. Like in the previous studies, the study is limited by the fact that it was applied in only one situation. The results demonstrate high level of acceptance by students and a positive alternative method for accounting teaching.

Articles five and six were presented at the international congress on active learning methods held in São Paulo in February 2010. In the first, "Application of the PBL method in the specialization course in controllership and finance”, the study presented the application of the PBL teaching method in an accounting subject taught in a lato sensu graduate program at an HEI in São Paulo State. The paper discusses approaches to the learning process and the application of PBL to controllership teaching in the course. In the second article, "Focus group applied to accounting teaching to assess students' perception on participation in role play", the application of the focus group method is discussed as an active learning method applied to accounting teaching in order to assess role play. Both papers present discussions on learning theories and approaches to the learning process. Limitations include the presentation of isolated research. The results indicate students' positive acceptance in both studies.

Research has demonstrated that active learning methods are used with positive results when compared with traditional teaching methods. Other knowledge areas, such as the health area, study the theme very thoroughly. In applied social science however, insufficient importance has been granted to quality improvement in the teaching-learning process and professional preparation courses.

These issues need to be discussed and, what is more, any educator and opinion maker needs to go deeper into learning theories. Besides preparing professionals in accounting and related areas, graduates are also citizens who, in a way, will make the future better than the present and will construct knowledge or continue the construction process.

\section{Final Considerations}

As an extremely technical area, accounting has shown indifference towards the use of active teaching methods. In Brazil, little research in this respect is found.

It is known that the professional competency demands accounting professionals are confronted and often exceed what accounting programs are preparing. More than 1200 higher education institutions offer accountancy courses in Brazil, few of which are discussing teaching methods in their politicalpedagogical projects. All of these institutions, however, have their respective projects and all of them are committed to preparing professionals with abilities that include, besides technical skills, critical analysis and interdisciplinary knowledge.

Using traditional teaching methods to prepare professionals who are able to solve problems in the real world, interprets situations and critically analyzes the cases they are confronted with will be quite a hard task.

Despite the few studies published, facilitating this learning process by using active methods has demonstrated students' efficiency and adherence to improve their learning process in comparison with traditional teaching methods. Similar proposals are successfully put in practice abroad.

This research is mainly limited by the fact that educational theories are not discussed as thoroughly as they should be. This limitation is justified by the fact that further discussion is needed in psychology and education as a knowledge area, which goes beyond the goal of this study. The research on learning theories mentioned here is just the tip of the iceberg. The survey of Brazilian authors' research using active learning methods, and in greater depth by international authors, starts a discussion process on the subject in which there is no way back. And that is exactly the goal of this research-to attract accounting researchers' attention to the importance of going deeper into this theme.

\section{REFERENCES}

Andrade, C. S. de (2002). O ensino de contabilidade introdutória nas universidades públicas do Brasil. f155. Dissertação (Mestrado em Controladoria e Contabilidade), São Paulo: Universidade de São Paulo.

Araujo, A. M. P. de, Fregonesi, M., Soares, M., \& Slomski, V. (2010). Aplicação do método problem-based learning (PBL) no de curso de especialização em controladoria e finanças. Congresso Internacional $P B L$. SP, Anais.

Araujo, A. M. P. De, \& Rodrigues, E. A. (2006). O ensino da contabilidade: Aplicação do método PBL nas disciplinas de contabilidade de uma Instituição de Ensino Superior Particular. 6th Congresso USP de controladoria e contabilidade, Anais, SP.

Bonner, S. E. (1999). Choosing teaching methods based on learning objectives: An integrative framework. Issues in Accounting Education, 11-39.

Cotell, J. R., Philip, G., \& Millis, \& Barbara J. (1992). Cooperative learning in accounting. Journal of Accounting Education, 10, 95-111. http://dx.doi.org/10.1016/0748-5751(92)90019-2

Freire, P. (1987) Pedagogia do oprimido (17th ed.). Rio de Janeiro: Paz e Terra.

Hand, L., Sanderson, P., \& O’Neil, M. (1996). Fostering deep and active learning through assessment. Issue in Accounting Education, 5, 103-119.

Hansen, J. D. (2006). Using problem-based learning in accounting. Journal of Education for Business, 81, 221-224. http://dx.doi.org/10.3200/JOEB.81.4.221-224

Johnstone, K. M., \& Biggs, S. F. (1998). Problem-based learning: Introduction, analysis, and accounting curricula implications. Journal of Accounting Education, 16, 407-427. http://dx.doi.org/10.1016/S0748-5751(98)00026-8

Kanet, J. J., \& Barut, M. (2003). Problem-based learning for production and operations management. Decision Sciences Journal of Innovative Education, 1, 99-118.

Leal, D. T. B., Casa, N., \& Silvia, P. de C. (2009). Métodos dramáticos aplicados a intervenções socioeducativas de autogestão e contabilidade. Revista de Educação e Pesquisa em Contabilidade, 3, 1-17.

Leif, J., \& Rustin, G. (1968). Pedagogia geral pelo estudo das doutrinas pedagógicas. Cia Editora Nacional.

Libâneo, J. C. (1994) Didática (p. 263). São Paulo: Cortez. 
Maher, M. W. (2000). Management accounting education at the millennium. Issues in Accounting Education, 15, 335.

Michell, W. S. (1962). Can accounting instruction be automated? Convenção American Accounting Association, Michigan.

http://www.jstor.org/pss/242357

Milne, M. J., \& McConnell, P. J. (2001). Problem-based learning: A pedagogy for using case material in accounting education. Issues in Accounting Education, 10, 61-82.

Mitre, S. M., Batista, R. S., Mendonça, J. M. G., Pinto, N. M. de M., Meirelles, C. de A. B., Porto, C. P., Moreira, T., \& Hoffmann, L. M. A. (2008). Metodologias ativas de ensino-aprendizagem na formação profissional em saúde: Debates atuais. Ciência \& Saúde Coletiva, 13, 2.

Mizukami, M. da G. N. (1986). Ensino: As abordagens do processo (p. 119). SP: EPU,

Nérici, I. G. (1977). Introdução à didática geral (12th ed., p. 402). RJ: Científica.

Neves, A. C. (2006). Reflexões sobre o ensino superior de contabilidade e a formação do contador. Revista do Conselho Regional de Con- tabilidade do Rio Grande do Sul, Porto Alegre, 18-29.

Shaftel, J., \& Shaftel, T. L. P. (2007). Educational Assessment and the AACSB. Issues in Accounting Education, 22, 215.

Skinner, B. F. (1999). A psicologia pode ser uma ciência da mente? Tradução: Hélio José Guilhardi e André Luis Jonas e revisto por Noreen Campbell de Aguirre.

www.iaac.com.br/textos/skinner/psicologiadamente.pdf

Soares, M. A., \& Araujo, A. M. P. de. (2008). Aplicação do método de ensino Problem Based Learning (PBL) no curso de Ciências Contábeis: Um estudo empírico. II Congresso ANPCONT, Salvador.

Soares, M. A., Araujo, A. M. P. De, \& Leal, E. A. (2008). Evidências empíricas da aplicação do método problem-based learning (PBL) na disciplina de contabilidade intermediária do curso de ciências contábeis. Enanpad, Rio de Janeiro.

Souza, L., \& Casa Nova, S. P. de C. (2010). Focus group aplicado ao ensino da contabilidade para avaliar a percepção dos discentes sobre a participação de um jogo de papéis (role play). Congresso Internacional PBL. Anais, SP. 